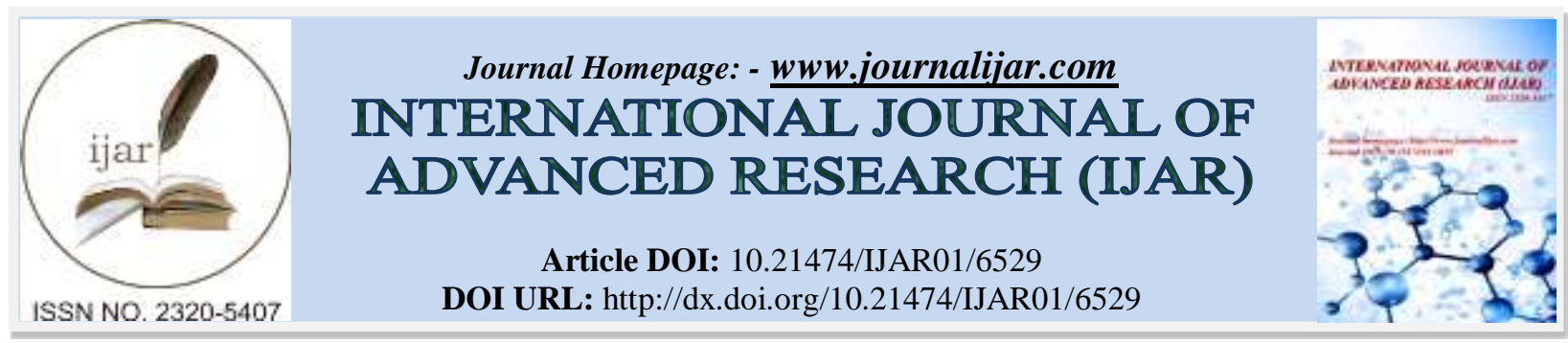

RESEARCH ARTICLE

\title{
TRACING STOMATAL ONTOGENY THOUGH FOLIAR HISTOCHEMICAL STUDY IN ACANTHACEAE.
}

Thara K Simon.

Department of Botany, Union Christian College, Aluva. Affiliated to Mahatma Gandhi University, Kottayam.

\section{Manuscript Info}

Manuscript History

Received: 14 December 2017

Final Accepted: 16 January 2018

Published: February 2018

Key words:-

stomata, Acanthaceae,

histochemistry, diacytic,

mesogenous, and mesoperigenous.

\section{Abstract}

The stomatal complex of Acanthaceae, is analysed correlating the evidences from ontogeny and histochemistry. In mature stomatal complex, the mesogenous subsidiary cells bracket the guard cells in a ' $C$ ' shaped manner. Due to the unusual curvature of the subsidiary cells, the epidermal cells adjacent to the stomatal complex also acquire a ' $C$ ' shape irrespective of their ontogeny which, are perigenous in origin how ever resemble mesogenous subsidiary cells morphologically. From ontogenetic point of view these cells may be referred to as perigenous encircling cells. The functional association of mesogenous subsidiary cells to guard cells is indicated by epidermal histochemisty. When tested with Mercuric Bromophenol Blue (MBB) for total proteins, the guard cells of Strobilanthes ciliatus showed deep blue colour while the subsidiary cells were clearly differentiated by the dark shade of the peripheral region due to metachromatic reddish hue with MBB. Staining reaction with Toluidine Blue 'O' indicated the presence of phenolic compounds with blue-green coloration in the diallelomesogenous complex of Justicia gendarussa. In Strobilanthes barbatus when tested for total lipids with Sudan III or IV, both guard cells and subsidiary cells were characterised by single large reddish orange lipid globules. These were absent in other epidermal cells and perigenous encircling cells. When subjected to PAS reaction, the mesogenous subsidiary cells of Peuderanthemum malabaricum gave less PAS positive results than both guard cells and epidermal cells. Epidermal histochemistry clearly distinguishes mesogenous stomatal complex from the morphologically similar perigenous cells and ordinary epidermal cells. The mesogenous subsidiary cells differ functionally from the morphologically similar perigenous encircling cells. These cells should be considered different from the diallelomesogenous' group of subsidiary cells characteristic of Acanthaceae. It is inferred that allelocytic stoma is mesogenous in origin and the terms mesoperigenous and diallelomesogenous are not applicable to acanthaceous stomata.

Copy Right, IJAR, 2018,. All rights reserved. 


\section{Introduction:-}

Since many decades, the stomatal complex of Acanthaceae has been a topic of deep interest among 'morphologists' and 'ontogenists'. It was Vesque (1889) who classified the stomata for the first time based on ontogeny and adult structure and included acanthaceous stomata in 'caryophyllaceous' group. Later Benecke (1892) and Solereder (1908) in their works gave brief descriptions of the epidermal features of this family and Metacalfe and Chalk (1950) suggested the widely accepted term 'diacytic' to the above group. In 1965 Pant recognised ten main ontogenetic types of stomata and laid down the ontogenetic system of classification. This was mainly on the basis of the terminology for gymnosperms created by Florin $(1931,1933)$. Further the term 'diallelocytic stomata' introduced by Payne (1970) was welcomed by all the contemporary workers viz. Rohweder, Schlumpf and Krattinger (1971), Fryns -Claessens Claessens and Van Cotthem (1973) Wilkinson (1979) and Inamdar, Mohan and Bagvathi Subramanian (1986) who assigned the stomatal complex of Acanthaceae to the 'diallelomesogenous group'. The elaborate classification of Fryns -Claessens and Van Cotthem (1973) bridges the gap between ontogeny and morphology. However there is disagreement about the concepts of mesoperigenous origin of subsidiary cells and the various terminologies are reviewed and modified from time to time (Stevens and Martin, 1978; Payne, 1979; Ramayya and Rajagopal, 1980; Rasmussen, 1981). An extensive work by Baranova (1992) discusses the history, classification and phylogenetic aspects of angiosperm stomata. The terminology of Fryns -Claessens and Van Cotthem (1973) and Payne (1979) are followed here and the stomatal meristamoid is referred to as the stomatocyte (Inamdar et al. 1986).

Pant and Mehra (1963) published the pioneering report on the stomatal development of Acanthaceae. Since then the number of subsidiary cells was limited to two by some workers (Paliwal, 1966; Kumar \& Paliwal, 1975 and Ahmad, 1974,1979), while others (Inamdar, 1970; Inamdar et al.1983; Rohweder et al. 1971; Hossain, 1974 and Kannabiran, 1977) considered the number as more than two. As the occurrence of more than two subsidiary cells in the stomatal apparatus has been established from the study of ontogeny and morphology, the functional association of subsidiary cells (Esau, 1965) and its role in stomatal classification is yet to be exploited. Moreover, Baranova (1992) points out that the definition of subsidiary cells differs in both morphologic and ontogenetic sense. Patel (1978) has suggested that though it is difficult to study the physiological aspects of stomata; the physiology of the subsidiary cell reflected in its morphology, histology and biochemistry may give a clue regarding the physiological status of stomatal complex. Histochemistry will help to localise the metabolites at a cellular level, which in turn are indicators of the physiology of the cell. The valuable contributions of Krishnamurthy (1988) and Vijayaraghavan and Shukla (1990) have added new dimensions to the methodologies to be followed. Kearns \&Assmann (1993) and Prakash \& Kumar (1995) have emphasised the significance of stomatographic studies in relation to the surrounding microenvironment. Recent studies of Patil \& Patil (2011), Verdam (2012) Jani S. \& H.C. Rudrappa (2014), Kumar et., al., (2014) Bhogaonkar \& Lande (2015), Choopan \& Grote (2015), and Noor-syaheera et., al., (2015) have emphasised the significance of leaf anatomical epidermal features of members of Acanthaceae. This study is carried out to find out the role of histochemistry in explaining the nature of stomatal complex of Acanthaceae.

The present study deals with the foliar epidermis of four representative taxa of the Acanthaceae such as Justicia gendarussa. Burm.f, Pseuderanthemum malabaricum. Gamb., Strobilanthes barbatus. Nees and S. cilatus. Nees.

\section{Materials and Methods:-}

Fresh foliar materials at different growth stages were collected from different localities of Kerala, India. Peelings from very young leaves were taken to study the ontogeny. Mature epidermal peels were subjected to various histochemical tests for localisation of different compounds (Krishnamurthy, 1988) as follows:

A. Insoluble polysaccharides - PAS reaction (Jensen, 1962).

B. Total proteins - Mercuric bromophenol blue (Mazia, Brewer and Alfert (1953).

C. Total lipids - Sudan dyes (Gomori, 1952).

D. Polyphenols - Toluidine Blue 'O' (Feder and Wolf, 1985, Mc Cully, 1966).

As the differential viability of the cells is subjected to various factors (Weyers \& Meidner, 1990) the tests (excluding total lipids, which was done on fresh specimens) were uniformly repeated on fresh as well as preserved materials.

\section{Results:-}

The study showed that stomata with two, three or four subsidiary cells occurred in Acanthaceae, all mesogenous in origin. However in Justicia gendarussa and Pseuderanthemum malabaricum, stomata with two or three subsidiary 
cells were frequently observed while in Strobilanthes ciliatus and S.barbatus, the stomata with four subsidiary cells were usually seen. In both the latter species, stomata with two subsidiary cells were not observed.

\section{Development of stomata:-}

In very young leaves, the meristamoids or 'stomatocytes' can be easily identified by their thin walls, dense staining properties and prominent nuclei. The stomatocyte divides by a curved wall into two unequal cells. The larger cell encircles about two-thirds of the smaller one. By a second division, the median cell again cuts off another cell towards the opposite direction. The central wall again divides twice in an alternate fashion, parallel to the first formed ones and pushes them outwards. Thus typically four subsidiary cells are developed (Fig.1, 1-6) as in the case of S.barbatus and S.ciliatus. In the case of Pseuderanthemum malbaricum and Justicia gendarussa only two or three mesogenous subsidiary cells are seen.

After cutting off the subsidiary cells, the stomatocyte functions as guard cell initial and divides to form two guard cells. They soon enlarge and start their function. Later, the subsidiary cells also enlarge to form the diallelocytic stomatal complex, purely mesogenous in origin.

\section{Morphology of the mature stomatal complex:-}

In the mature stomatal complex, the mesogenous subsidiary cells bracket the guard cells in a ' $\mathrm{C}$ ' shaped manner. Due to the unusual curvature of the subsidiary cells, the epidermal cells adjacent to the stomatal complex also acquire a ' $C$ ' shape irrespective of their ontogeny. Even though these cells are perigenous in origin, morphologically they resemble the mesogenous subsidiary cells. (From the ontogenetic point of view these cells may be referred to as perigenous encircling cells (p.e.c. fig.1.6).

\section{Histochemical localisation:-}

a) Total proteins: When stained with Mercuric bromophenol blue, the stomatal complex of Strobilanthes ciliatus, Nees showed a positive staining reaction (Fig.1-A). The cytoplasmic granules and nuclei showed deep blue coloration, while the subsidiary cells were clearly distinguished by the dark shade of the peripheral region. The darker shade in the peripheral region of subsidiary cells with Mercuric Bromophenol Blue may be due to more concentrated proteins and also due to the presence of discrete protein bodies. The degree of dye binding due to more concentrated proteins may produce a metachromatic reddish hue with MBB. The cells morphologically similar to the mesogenous subsidiary did not show such intense reaction and appeared as an epidermal cell.

b) Polyphenols: The staining reaction with Toluidine Blue 'O' showed the presence of phenolic compounds in the diallelomesogenous complex of Justicia gendarussa with a blue-green coloration. (Fig. 2 B)

c) Total lipids: Strobilanthes barbatus when stained with Sudan III or IV gave large lipid globules confined to the stomatal complex (Fig. 2 C). Each guard cell and subsidiary cell was characterised by a single oil globule. Though such globules were seen in the palisade cells, in normal epidermal cells they were absent.

d) Insoluble polysaccharides: When subjected to PAS reaction, the mesogenous subsidiary cells of Peuderanthemum malabaricum gave less PAS positive results than the guard cells, epidermal cells and cell wall (Fig 2 D). This may be attributed to the utilisation of insoluble polysaccharides in providing energy and metabolic substrates for the differentiating cells.

All the above histochemical tests clearly distinguish the mesogenous stomatal complex from the morphologically similar perigenous cells and ordinary epidermal cells.

\section{Discussions and Conclusion:-}

The selective staining reactions shown by the mesogenous subsidiary cells can be attributed to the metabolic activities of the stomatal complex. While staining with Sudan IV, due to the differentiation of the specimen in $70 \%$ alcohol prior to staining, lipid meioty tends to dump together as the protein component of the cytoplasm is precipitated and the disulphide bonds are broken. This is in keeping with the reports of Pearse (1972).

The PAS positive reaction (Fig. 2 D) is in conformity with the physiological activities of the stomatal complex (Haberlandt, 1914; Meidner and Mansfield, 1968). The reactions with Mercuric bromophenol blue as well as TBO (Fig. 2 A, B) show the functional association of subsidiary cells in the metabolism of polyphenols and proteins. Thus with a functional approach, (as a criterion along with the morpho -ontogenic approaches); the allelocytic stomata has to be considered as a mesogenous complex. 
In Justicia gendarussa and Pseuderanthemum malabaricum, stomata with two or three subsidiary cells are seen among the epidermal cells. The present observation is in keeping with the view of Rohweder et al. (1971) that the diacytic stomata should not be divided into two or more groups on the basis of the number of subsidiary cells, but should be grouped under Payne's (1970) allelocytic group as also accepted by Fryns -Claessens and Van Cotthem (1973). They also suggest the elimination of the term 'diacytic'. However, the terms 'diamesogenous' and 'diallelomesogenous' are useful in distinguishing the stomata with two or more subsidiary cells.

In the case of Strobilanthes barbatus and S.ciliatus outer to the fourth mesogenous subsidiary cell, a fifth cell also takes the shape of a subsidiary cell. This phenomenon is also observed around the diamesogenous and diallelomesogenous subsidiary cells of Pseuderanthemum malabaricum and Justice gendarussa. As these cells do not show any staining reactions similar to the mesogenous subsidiary cells, the morphological resemblance is only due to the spatial adjustments of the adjacent cells. The histochemical observations are also in support of this view. It is also suggested that any adjacent cell resembling the subsidiary cell morphologically, should be termed as a 'perigenous encircling cell' (p.e.c. Fig. 1-6) and should be kept apart from the allelomesogenous group. In order to avoid confusion, this term should be confined to the cells of perigenous origin. Further, the term, 'diallelomesoperigenous' (Kannabiran, 1977), as proposed by Kannabiran and Krishnamurthy (1979) should be eliminated. In this context, the mesoperigenous concept of Pant (1965) cannot be applied to the stomata of Acanthaceae.

Ahmad (1979) after observing the mature acanthaceous stomata, came to the conclusion that there are only two subsidiary cells supporting the views of Paliwal (1966) and Kumar and Paliwal (1975). The present study reveals that stomata with two, three or four subsidiary cells can be seen mixed among the normal epidermal cells. These observations are in keeping with the views of Pant \& Mehra (1963), Inamdar (1970), Inamdar et al. (1983), Rohweder et al. (1971), Hossain (1974) and Kannabiran (1977).

Guyot (1971) points out that the function of guard mother cell (g.m.c) is a remarkable phenomenon and it is the number of divisions that form a real basis for the classification of stomatal types. The present study also emphasises the individuality of the stomatal initial and it is more appropriate to call it as a 'stomatocyte' (Inamdar, et al. 1986), rather than considering it to be the 'residual protodermal cell' as suggested by Patel (1978). The thought provoking publication of Payne (1979) shows that the mesogenous subsidiary cells or a stomatal complex differ physiologically and structurally from the epidermal cells. Patel (1978) strikingly describes the significance of histochemistry as an aid to the identification of subsidiary cells. In the present study, the mesogenous stomatal complex showed selective staining reactions for the localisation total lipids, total proteins, Polyphenols and polysaccharides. The reactions of perigenous encircling cells were similar to that of the epidermal cells. Thus with a functional approach (as a criteria along with the morpho-ontogenic approaches), histochemistry favours ontogeny rather than morphology.

On a related point, while discussing the functional importance of mesogenous subsidiary cells of Vigna sinenris, Galatis (1977) states 'it can be said that the subsidiary cells of Vigna sinensis are actually guard cells in their structure and possibly in some functional activities, though they lack their form'. The present histochemical observations are in support of this view.

Ahmad (1979) in his extensive studies, used the cuticular aspects of Acanthaceae, to explore the taxonomic significance of the family. Raju \& Shah (1975) and Patel (1978) have noted the significance of histochemistry as an aid to the identification of subsidiary cells. Our investigation indicates that both these aspects together can contribute much more to solve the taxonomic problems of this interesting and challenging family and further work is in progress to elucidate the systematic significance of cuticular histochemistry in Acanthaceae.

\section{Acknowledgements:-}

We thank Dr. E. C. Raju, Dr. K. V. Krishnamurthy, Dr. M. R. Vijayaraghavan and Dr. C. J. Mathew for their critical suggestions. 

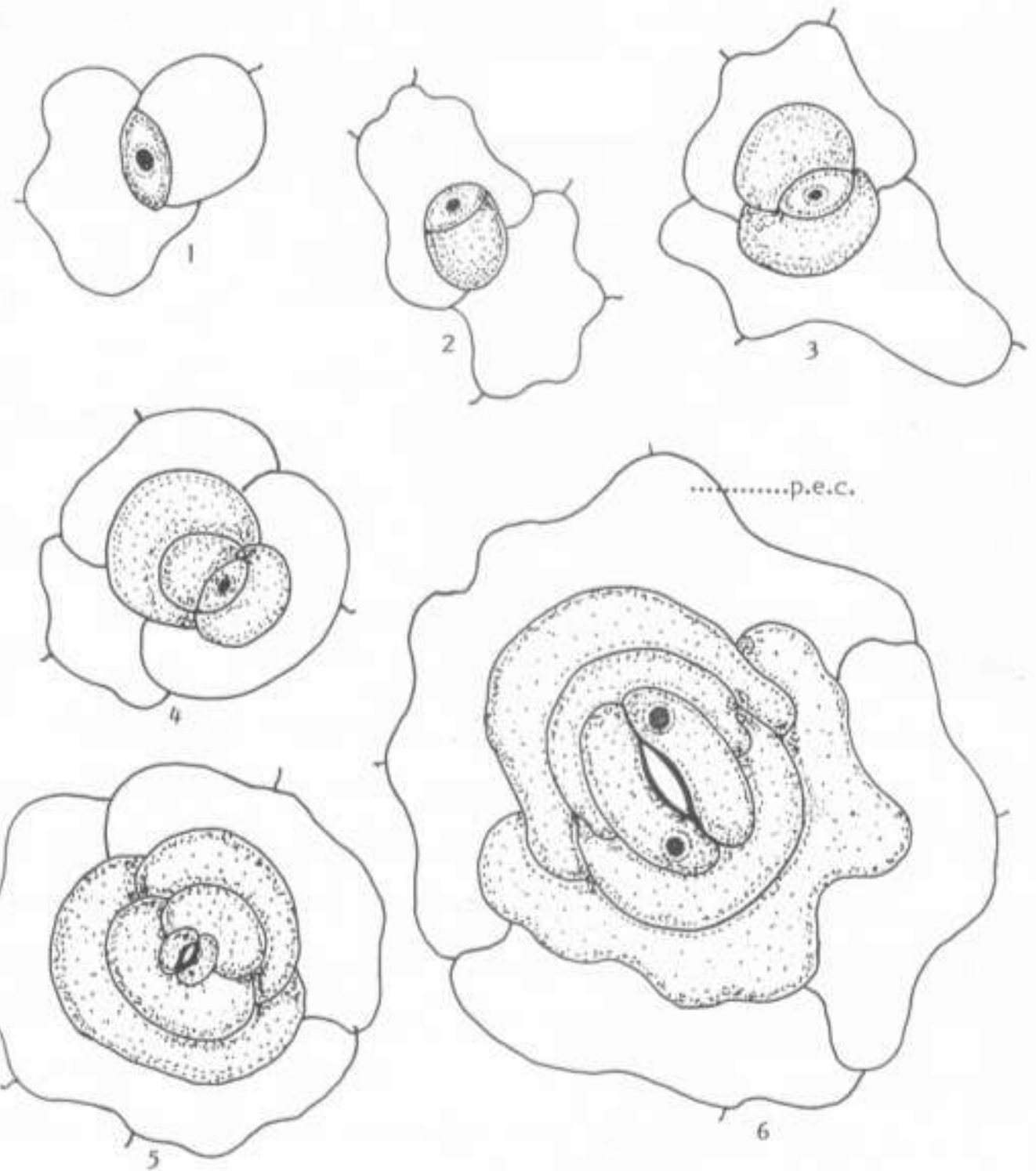

Fig. 1, 1 - 6:- Stomatal development in Strobilanthes barbatus Nees, formation of diallelomesogenous stomata with four subsidiary cells. p.e.c. - perigenous encircling cell. 


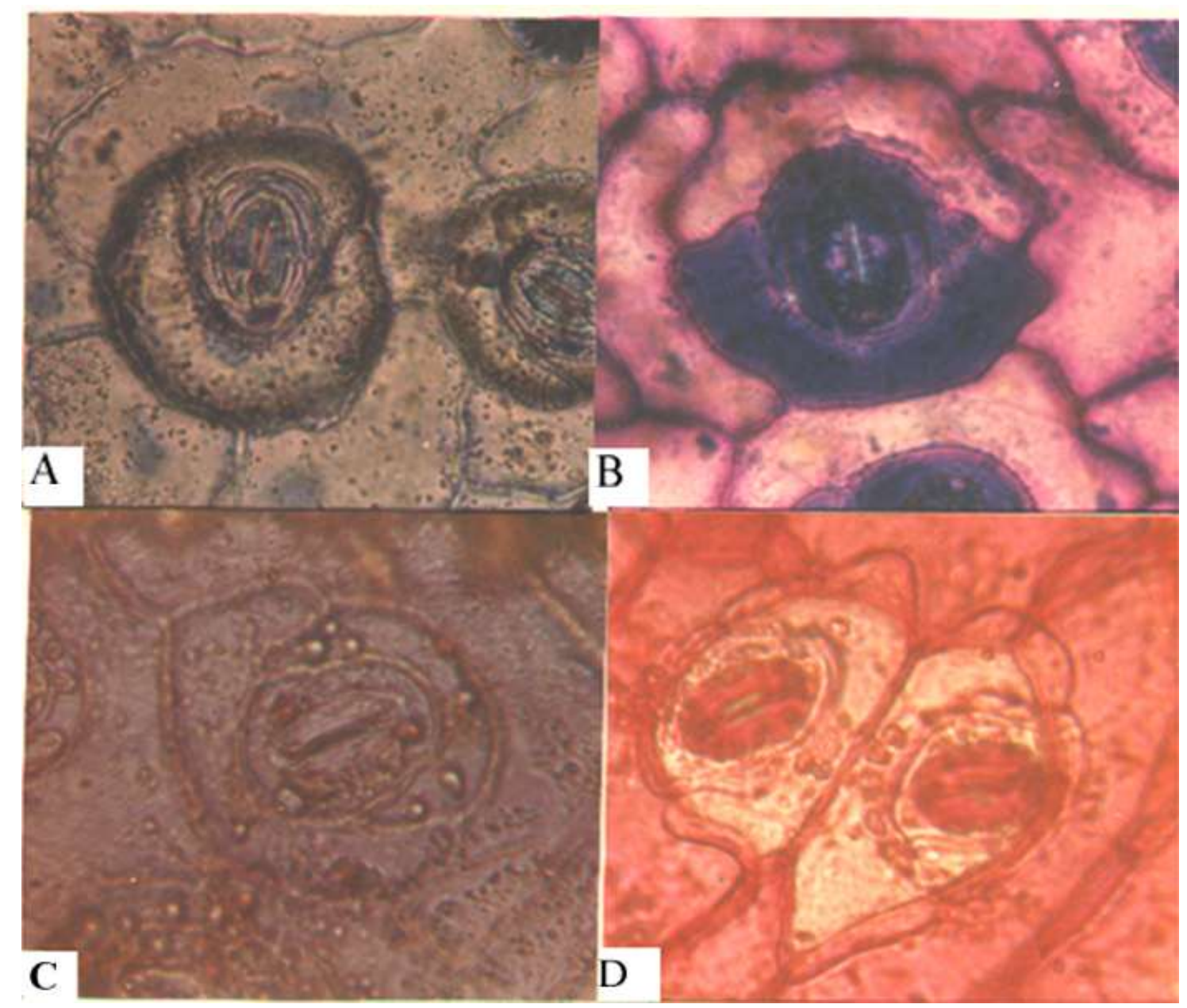

Figure - 2

A. Strobilanthes ciliatus, Nees: Stomatal complex stained with Mercuric bromophenol blue for proteins-note the deep coloration of the mesogenous subsidiary cells.

B. Justicia gendarussa. Burm $\mathrm{f}$ : Stained with TBO - the phenolic compounds confined to the guard cells and mesogenous subsidiary cells.

C. S.barbatus, Nees: Stained with Sudan III - note the large lipid globules confined to the guard cells and mesogenous subsidiary cells.

D. Pseuderanthemum malabaricum, Gamb. PAS reaction - the guard cells and cell walls show deep red colour while the mesogenous subsidiary cells are lightly stained indicating their identity. 


\section{References:-}

1. Ahmad, K.J. 1974. Cuticular studies in some species of Hemigraphis and Strobilanthes. Porch. Indian Acad. Sci. LXXIX B: 21-40.

2. Ahmad, K.J. 1979. Stomatal features of Acanthaceae. In 'Structure and function of stomata' 43-60. Bishen Singh Mahendra Pal Singh. Dehra Dun.

3. Baranova, 1992. Principles of comparative stomatographic studies Bot. Rev. 58(1): 49-97.

4. Benecke, W. 1892. Die Nebenzellen der Spaltoffungen. Bot Zet. 50: 521-607.

5. Bhogaonkar, P.Y. \& S.K. Lande 2015. Anatomical characterization of Lepidagathis cristata Willd.- A Ethanomedicinal herb. Journal of global biosciences 4(5):2282-2288.

6. Esau, K. 1965. Plant Anatomy, New York.

7. Choopan, T. and Paul J. Grote 2015. Cystoliths in the leaves of the genus Pseuderanthemum (Acanthaceae) in Thailand. International Journal of Science 12(2) : $13-20$.

8. Feder, N. and Wolf, M.K. 1965. Studies on the nucleic acid metachromacy II.. Metachromatic and Orthochromatic stalinilng by Tolulidine Blue of nucleic acid in tissue sections. J. Cell Biol. 27: 327-336.

9. Florin, R. 1931. Untersuchungen zzur Stammesgeschichte der Coniferiles und Cordaitales. K.Svensk. Vetenskaps. Handl. III . 10 (1):1-588.

10. Florin, R. 1933 Studien uber die Cycadales des Mesozoikums... Erorterung uber die

11. Spaltoffnungsapparate ver Bennettitales. K.Svensk. Vetenskaps. Handl. III . 12(5): 1-134.

12. Fryns -Claessens -Claessens, E and Van Cotthem, W. 1973. A new classification of the ontogenic type of stomata. Bot. Rec. 39: 71:138.

13. Galatis, B. 1977 Differentiation of Stomatal meristamides and guard mother cell in Vigna sinensis leaves after colchicine treatment Planta 136: 103-114.

14. Gomori, G. 1952. Microscopic Histochemistry, Principles and Practice. Univ. of Chicago press, Chicago Illinois.

15. Guyot, M. 1971. Phylogenetic and systematic value of stomata of Umbellilferae. Bot.

16. J. Linn. Soc. (Suppl. I), 64: 199-214.

17. Haberlandt, G. 1914 Physiological plant anatomy. Mac Millan \& Co. London.

18. Hossain, A.B.M.E. 1974. Studies in Acanthaceae tribe Nelsonieae II, Foliar Sclereids and stomata. Notes R.B.G. Edinb. 33: 269-274.

19. Inamdar, J.A. 1970. Epidermal structure and ontogeny of caryophyllaceous stomata in some Acanthaceae. Bot. Gaz. 131 (4) : 261-268.

20. Inamdar, J. A. Bhatt, D.C. and Chaudhary, G.S. 1983. Structure and development of stomata in some Acanthaceae. Proc. Indian Acad, Sci. (Plant Sci.) 92 (3) : 285-296.

21. Jani, S. and H.C. Rudrappa 2014. Morphological, structural and micrometric study of cystolith of family Acanthaeceae W.S.R. to Kalmegh. International Journal of Green Pharmacy .

22. Inamdar. J.A., Mohan, J.J.S. and Bhagavathi Subramanian. 1986. Stomatal classifications - a review. Feddes Repert. 97, 3-4: 147-160.

23. Jensen, W.A. 1962. Botanical Histochemistry. Free man, Sanfrancisco.

24. Kannabiran, B. 1977. Foliar epidermis and ontogeny of stomata in Ecbolium linneanum, Kurz. Proc. Indian Acad. Sci, 86B: 381-384.

25. Kannabiran, B. and Krishnamurthy, K. 1979. Stomatal ontogeny in some Dicotyledonous families with special reference to its taxonomic and phylogenetic value. In 'Structure and function of stomata' 23-41.Bishen Singh Mahendra Pal Singh. Dehra Dun.

26. Kearns, E.V. and Assmann, S. M. 1993. Guard cell-Environment connection. Plant Physiol. 102:711-715.

27. Krishnamurthy, K.V. 1988. Methods in Plant Histochemistry. S. Viswanathan, Madras.

28. Kumar, S. and Paliwal, G.S. 1975. Foliar anatomy of the family Acanthaceae II. The tribes Thunbergieae and Nelsonieae. Acta. Bot. Indica 3: 121-131.

29. Kumar R.S., Reddy R.P., Rao S.G.\& K. Nethaji 2014. Botanical Pharmacognosy on the Leaves of Medicinally Important Plant Andrographis paniculata (nees) Collected from the Forest Area of Medak District, Andhra Pradesh, India. Int. J. Pharm. Sci. Rev. Res., 25(2):292-295.

30. Mazia, D., Brewer, P.A. and Alfert, M. 1953. Cytological staining measurement of protein with Mercuric Bromophenol blue. Biol. Bull. 104: 57-67.

31. Meidner H and Mansfield T A 1968 Physiology of Stomata. McGraw-Hill, London and Newyork.

32. Metcalfe, C.R. and Chalk, L. 1950. Anatomy of Dicotyledons. 1950. Clarendon press, Oxford.

33. Mc. Cully, M.E. 1966. Histological studies on the genus Ficus. I Light microscopy of the mature vegetative plant. Protoplasma: 62: 287-305. 
34. Noor-syaheera M.Y., Noraini T., Radhiah A.K. \& C. A. C. Che-nurul-Aini 2015. Leaf anatomical characteristics of Avicennia L.and some selected taxa in Acanthaceae. Malayan Nature Journal 67(1): 81-94.

35. Paliwal, G.S. 1966. Structure and ontogeny of stomata in some Acanthaceae. Phytomorphology 16 (4): $527-$ 532.

36. Pant, D. D. 1965. On the ontogeny of stomata and other homologous structures. Plant Sci. Ser. (Allahabad). 1: $1-24$.

37. Pant, D.D. and Mehra, B. 1963. Development of caryophyllaceous stomata in Asteracantha longifolia Nees. Ann Bot. 27: 647-652.

38. Patel, J. D. 1978. How should we interpret and distinguish subsidiary cells ? Bot. J. Linn. Soc. 77: 65-72.

39. Patil A.M. \& D.A Patil 2011. Occurrence and significance of cystoliths in Acanthaceae. J. Curr. Bot. 2(4): 0105.

40. Payne, W.W. 1970. Helicocytic and allelocytic stomata: Unrecognised patterns in the

41. Dicotyledonae. Amer. J. Bot. 57 (2) : 140-147.

42. Pearse A. G. E. 1985. Histochemistry, theoretical and applied Vols. I \& II Chruchill, London.

43. Praksh, G. and Kumar, V. 1995. Stomatal study on defence organs by conservation facsimile method. J. Indian Bot. Soc.74: 263-268.

44. Raju, E.C. and Shah, J.J. 1975. Studies in Stomata of Ginger, Turmeric and Mango Ginger. Flora, Bd. 164, S: 19-28.

45. Ramayya, N and Rajagopal T. 1980 Classification of subsidiary cells according to inter stomatal space relationships Current Science 49: 671-673.

46. Rasmussen, H. 1981. Terminology and Classification of Stomata and Stomatal Development- A Critical Survey Bot. J. Linn. Soc. 83: 199-212.

47. Rohweder, O., Schlumpf, R. and Krattinger, K. 1971. Anmerkungen zum diacytischen Spaltoffnungstyp and zur taxonomischen Bedeutung der Spaltioffnungen in allgemeinen. Ber. Dtsch. Bor. Ges. 84 (5) : 275-285.

48. Solereder, H.1908. Systematic anatomy of the Dicotyledons. Clarendon Press, Oxford.

49. Stevens, R A. and Martin E. S. 1978. A new ontogenetic classification of Stomatal types Bot. J. Linn. Soc 77: 53-64

50. Verdam, Maria C.S., Ohana D.T., Araújo Maria G. P., Guilhon Simplicio F., Mendonça M. S. de, M.M. Pereira 2012. Morphology and anatomy of Justicia acuminatissima leaves. Revista Brasileira de Farmacognosia Brazilian Journal of Pharmacognosy. Rev. bras. farmacogn. vol.22 no.6.

51. Vesque, I. 1889. De 1' emploi des Caracteres anatomiques dans la Classification des Vegetaux. Bull. Soc. Bot. France. 36: 47-77.

52. Vijayaraghavan, M.R. and SHUKLA, A.C. 1990. Histochemistry: Theory and Practice. Bishen Singh Mahendra Pal Singh Dehra Dun.

53. Weyers and Meidner 1990. Methods in Plant Physiology, Longman.

54. Wilkinson H.P. 1979. 'The plant surface mainly leaf' pp 97-165.In Metcalfe CR and Chalk L - Anatomy of Dicotyledons I Edn. Clarendon Press, Oxford. 